Article

\title{
Touristic Stakeholders' Perceptions about the Smart Tourism Destination Concept in Puerto Vallarta, Jalisco, Mexico
}

\author{
José Luis Cornejo Ortega ${ }^{1, *}$ and Christopher D. Malcolm ${ }^{2}$ \\ 1 Departamento de Estudios socioeconómicos, Centro Universitario de la Costa, Universidad de Guadalajara, \\ Puerto Vallarta 48280, Mexico \\ 2 Department of Geography, Brandon University, Brandon, MB R7A 6A9, Canada; malcolmC@BrandonU.CA \\ * Correspondence: jose.cornejo@cuc.udg.mx
}

Received: 30 January 2020; Accepted: 23 February 2020; Published: 26 February 2020

check for updates

\begin{abstract}
The smart tourism destination (STD) is an adaptation of the smart-city concept into a tourism destination. Smart cities relate to the urban use of technologies and internet in order to improve economic growth, quality of life, efficient management of resources, and generation of governance processes and social participation. This paper aims to highlight the perception that different tourism experts in Puerto Vallarta have about intelligent tourism destinations. The working method of this research was through a Delphi study to analyze the responses of local experts on the status of STD's and their future trends. The experts' perceptions on the concept's definition, regional capacity for innovation, technological components, linking, and sustainability was analyzed. Experts perceived an optimistic scenario for STD in Puerto Vallarta, Jalisco, México. The participants in this study value the factors that determine the implementation of STDs as determinants; there are at least three of them: Training, Investment, and Governance.
\end{abstract}

Keywords: governance; stakeholder collaboration; smart tourism destination; smart city; social participation; information and communication technologies (ICT)

\section{Introduction}

Smart cities are related to the urban use of technology and the Internet, in order to improve economic growth, quality of life, efficient management of resources, and to generate governance and social participation processes [1]. They are configured as places where the use of technological tools is encouraged, such as sensors that provide real-time response to generate a specific form of intelligence and territorial innovation. Among the distinctive elements of a smart city are a commitment to social innovation, community development, and citizen participation. These elements are based on three structural pillars: human capital, infrastructure, and information [2].

Smart cities are the initial reference model for smart tourist destinations (STDs) to the extent that these are also essentially urban spaces. In fact, tourism activity is highly conducive to an alliance with urban development strategies that pursue territorial intelligence objectives, if we take into account the elements that characterize it [3].

The individual regional characteristics of tourist destinations must be taken into account and justify the application of a specific approach to the configuration of a smart tourism destination. The basic difference between smart cities and STDs lies in the fact that, in STDs, the focus is not on permanent residents but on the temporary visitors that visit the city for different reasons [4]. Therefore, a key aspect of STDs is considered to be the integration of information and communication technologies (ICT) into their physical tourism infrastructure. 
To carry out this research, it is necessary to start by defining what 'information and communication technologies' means, especially since it is a widely used term that nevertheless seems to vary according to the source consulted; it does not, in fact, seem to possess a consensual definition [5].

In the context of knowledge societies, these technological media can contribute to educational, labor, political, economic, and social welfare development, among other areas of daily life [5] (p. 312).

Buhalis, one of the most cited authors in the international academic literature related to the study of tourism in recent decades [6], at an international seminar of the World Tourism Organization (UNWTO), indicated that information and communications technologies constitute "the whole set of electronic tools that facilitate the operational and strategic management of companies, allowing them manage information, functions, and processes, as well as establish interactive communication with other interested parties to achieve their mission and objectives" [7]. Thus, information and communications technologies make up an integrated networked software and equipment system that allows effective data processing and communication, which benefit companies by allowing them to conduct electronic business [7] (p. 8).

The tourism sector is no stranger to the global trend in terms of the increasing adoption of ICTs, in fact, according to data from the sector analysis report and ICT implementation [8]. The relevance of this field of study is prevalent in the literature [9], which illustrates the strategic role of ICT in tourism academe. There are also two international scientific congresses on this subject that have been held for decades, the eTourism Conference ENTER and Tourism Information and Communication Technologies (TURITEC), which between them have published more than thirty-six editions. In recent years, authors, such as Buhalis and Law [10], Miralbell, Lamsfus and Gomis [11], González [2], and Parra and Santana [12], have explored national and international scientific publications on the ICT-Tourism binomial relationship. There are three main areas of research in this field: ICT and its relationship with tourism demand, ICT and its relationship with tourism innovation, and ICT and its relationship with new tourism business models.

The concept of the Smart Tourist Destination is the result of the transfer of the Smart City urban approach to tourist destinations [13]. The concept of Smart Tourism in Western countries was coined in the year 2000 by Gordon Philips [14] in adopting a holistic, long-term, and sustainable approach in order to plan, develop, operate, and market products and tourism businesses.

According to Gretzel, Sigala, Xiang, and Koo [15], Smart Tourism is a logical evolution of traditional tourism, and more recently, from so-called e-tourism, focused on business-consumer and consumer-consumer connections through the World Wide Web.

STD makes use of three main components of ICT: Cloud Services, the Internet of Things (IoT), and End-User Internet Service System [16]. First, according to Reference [17], cloud services are designed to provide convenient and scalable access (e.g., measurable for payment per use) to applications, software, and data through web browsers. For example, a sophisticated tour guide system can serve a large number of tourists without being installed on any personal device [18]. The STD initiative, coined officially by China's State Council of Chinese Central Government in 2009, refers to a platform on which information relating to tourist activities, the consumption of tourism products, and the status of tourism resources can be instantly integrated and then provided to tourists, enterprises, and organizations through a variety of end-user devices [19].

The spectacular growth of social media and user-generated content (UGC) on the Internet provides a huge quantity of information that allows for firsthand exposure to the experiences, opinions, and feelings of tourism 'users' or customers [20,21]. In the field of tourism, most authors agree on the importance of UGC [22,23] in the construction of destination image through the electronic word of mouth (eWOM) effect [24,25], and consider travel blogs, online travel reviews (OTRs), or online consumer reviews as rich sources of UGC data [21,26].

The Spanish approach to smart tourism development was conceived on a local scale basis and smart initiatives were focused mainly in cities [27]. For example, Barcelona is leading smart city, chosen in 2011 as the GSMA Mobile World Capital from 2012 to 2018, and was granted European Capital 
of Innovation ('iCapital') status by the European Commission (2014) for introducing the use of new technologies to bring the city closer to its citizens [28]. According to Wang, Li, and Li [18], the use of big data by smart tourism destinations can support business decision-making and optimal resource allocation, and can assist in the discovery of new insights in ways that affect markets and organizations.

Different authors express the importance of having the resident population in agreement at the time of implementing smart tourism strategies in the destinations. One of the requirements of STDs is that the local population is constantly digitally connected, so that they have a high capacity for creativity and empowerment, are experienced in the use of technology, and are actively involved in digital culture [29]. The STD also fundamentally requires the implementation of technological development strategies, such as the design of open information systems that allow real-time information for all citizens, prevent the emergence of monopolies [30], and also ensure the opportunity for citizen participation in the creation of strategies and subsequent monitoring of development and activities. To ensure that STDs improve local sustainability, they not only must improve the conditions of the visit for tourists, but they must also be built in constant dialogue with local actors and the resident population to ensure that the benefits of the sector can be distributed optimally among the local society [31].

Amid this tourist-technological crossroads, Celdrán et al. [32] identify and characterize the scientific production associated with the concept of intelligent tourism or "Smart Tourism". They state that "Smart Tourism" is a fashion label that we seek to clarify in its application to the tourism domain through the development of a systematic mapping study [32].

The key to innovation and technological orientation of industry and consumers was established with the adoption of information and communication technologies in tourism [32]. Given the intensity of tourism information and the high dependence resulting from information and communication technologies (ICT) $[33,34]$, it is not surprising to see the concept of smart applied to phenomena that cover tourism.

However, Smart Tourism is undoubtedly a different step in the evolution of ICT in tourism, since the physical and governance dimensions of tourism are entering into a digital game field and new levels of intelligence are reached in the tourist system [35]. On the one hand, it refers to smart destinations, which are special cases of smart cities: they apply smart city principles to urban or rural areas and not only consider residents but also tourists in their efforts to support mobility, availability and allocation of resources, sustainability, and quality of life/visits [15].

González et al. [2] highlights the perception of different tourism experts about STDs in order to obtain qualitative information so that, in the future, it can be used to address the management needs of STDs. The research aims to add elements of debate about the visions that can condition the attitudes and strategies of the SDT projects and pilot plans that are beginning to emerge in Spain.

In Mexico, there are only two STDs registered with the State Society for the Management of Innovation and Tourism Technologies (SEGITTUR), an agency within the Spanish Ministry. The first to be identified was Cozumel, which uniquely combines historical and pre-Columbian tourism attractions with accessibility to new technologies. To achieve this, the Mexican Ministry of Tourism and SEGITTUR, collaborated to develop this model in Cozumel, with great tourist, economic, and development regional success. According to Forbes [36], Cozumel has assumed this distinction as an engine to drive improvements in communications and digital tourism services infrastructure, which attracts new business models to the area.

The other STD in Mexico is Tequila, in the state of Jalisco, where. cultural richness is combined technological development. Despite being listed as a Magic Town, this has not prevented it from moving forward in the implementation of the latest generation of digital systems. With a new urban development plan, Tequila has been working since 2010 in "areas of strategy, administration, security, health, education, culture, environmental sustainability, social services and transport, among many other specific sections that form this type of Destinations". This ITC development has improved Tequila's tourism industry, since, in addition to its colonial buildings, its new Spanish streets and 
its tradition in the production of tequila, including iconic Tequila production houses, they have also developed advanced digital infrastructure.

Puerto Vallarta is a coastal municipality and tourist city in Jalisco state, Mexico. In 2020, Puerto Vallarta has an estimated population of 304,141 [37], 4,372,307 annual tourists in 2017, and is projected to be more than five million in 2020 [38]. Puerto Vallarta is the second most important economic zone in the state of Jalisco and the third most important port in Mexico. Currently, it is one of the most visited places in the country, ranking among the top three places in terms of receiving visitors; therefore, tourism is the basis of the local economy. In fact, there is an excessive concentration of economic activity around tourism, since close to $80 \%$ of Puerto Vallarta jobs are related to tourism activities. Its high dependence on tourism activity makes it very vulnerable to possible contingencies in the sector [38].

Puerto Vallarta, as a consolidated beach destination, is an ideal location to develop STD capacity due to the multiple tourism opportunities that are available in and around the city. In this paper, we explore this possibility by collecting perceptions of different tourism experts in Puerto Vallarta, regarding the STD concept.

\section{Methods}

The working method of this research utilized a Delphi approach organized to analyze the responses of different experts on the current reality of STDs, their future trends, and the possibilities of adopting such an approach in Puerto Vallarta. The purpose of this approach was also to obtain quantitative information that could be used in the any future endeavors to establish an STD in Puerto Vallarta. The collected data allowed us to analyze the extent to which agreement exists on what is understood by STD, as well as what its orientation, objectives, and mission should be. The data also provided us with information on the assessment of the conditions and requirements faced by destinations in order to apply STD strategies, as well as on the opportunities and risks that smart tourism implies for the competitiveness of the destination [2]. A questionnaire was designed in Spanish; after data was collected, it was translated to English, and a Likert scale was used.

The Delphi method is a technique to identify future projections, on which management decisions can be based, formed mainly from the ideas and impressions of informed individuals (i.e., stakeholders), rather than from predictions derived from theoretical assumptions $[39,40]$.

The Delphi is a method of structuring of communication process that is effective in allowing a group of individuals as a whole to deal with a complex problem. The Delphi starts from the basis that, despite the uncertainty of the future, the probability that any hypothesis will occur can be obtained by individuals trained to make informed judgments about the perspectives in a determined area of knowledge [2].

The organizational structure of a Delphi approach is based on the following aspects:

- Iterative process. Experts have to be consulted, at least, twice, so that they can rethink their response aided by the information they receive from the opinions of other experts.

- Maintains the anonymity of the participants in relation to their responses. It is about developing a group process with experts who do not coincide in time or space and avoid negative reciprocal influences.

- Controlled feedback. The group results are superior to the individual ones thanks to the interaction generated by the coordinator.

- There is a statistical group response. The questions must be formulated in a way that allows statistical treatment.

Seventeen national and international tourism specialists in Puerto Vallarta agreed to take part in the study; the group was composed of three profiles: (1) specialists and academic and professional experts ( $29 \%$ of experts); (2) tourism service providers ( $41 \%$ of experts); and (3) tourism sector authorities ( $29 \%$ of experts). 
The conventional Delphi method was used, in which a team coordinator administered the questionnaire to the experts to complete. The coordinator, having tabulated the results, administered the questionnaire again in an iterative process that guarantees effective communication between the researcher and the participant. It is a prospective study with a global and integrative orientation as defined through the network system under a single coordination and in which the estimate is not unique, but each expert offers consecutive estimates for the same phenomenon studied [41].

Fieldwork was carried out between March and July of 2019. The questionnaire includes five blocks of questions asking for general information on the characteristics of STDs, perceptions about trends and forecasts for the future, the components of the tourist system of the STDs, the technological aspects, the sustainability elements, the existing limitations and risks, and the conditions for the implementation of smart tourism strategies, adapted from González et al. [2]. Finally, frequencies were analyzed and a factor analysis was performed using SPSS®statistical software.

\section{Results and Discussion}

The first section of the questionnaire contained items related to the mission and fundamental objectives of STDs.

From Table 1, it can be concluded that that the participants have a clear conceptualization of STDs. All variables have values above three, except the variable: "The STDs respond more to a fashion concept or a poorly defined denomination than to a verifiable reality", which is 2.71 . However, this variable responds in reverse, with an average of the means of 3.87, higher than the one found by González et al. [2] in his study conducted in Spain (3.50).

Table 1. Descriptive statistics of the assessment of experts on the concept of smart tourism destination (STD) and its strategic orientation.

\begin{tabular}{|c|c|c|c|c|}
\hline Objectives and Mission & $\mathbf{N}$ & Mode & Mean & Std. Deviation \\
\hline \multicolumn{5}{|l|}{ STD Concept } \\
\hline $\begin{array}{l}\text { STDs have specific features that characterize them and allow them to } \\
\text { differentiate from other tourist destinations. }\end{array}$ & 17 & 5 & 4.41 & 0.870 \\
\hline $\begin{array}{l}\text { STDs respond more to a fashion concept or a poorly defined denomination } \\
\text { than to a verifiable reality. }\end{array}$ & 17 & 2 & 2.71 & 0.985 \\
\hline There is a clear and widely accepted definition of what an STD is. & 17 & 4 & 3.12 & 1.317 \\
\hline \multicolumn{5}{|l|}{ Role of sustainability in strategic orientation } \\
\hline $\begin{array}{l}\text { Technology and innovation in tourism should be the main strategic component } \\
\text { of an STD. }\end{array}$ & 17 & 4 & 3.41 & 1.326 \\
\hline Sustainability and equity should be the main strategic component of an STD. & 17 & 4 & 4.00 & 0.866 \\
\hline $\begin{array}{l}\text { Efficiency in the provision of tourism services should be the main strategic } \\
\text { component of an STD. }\end{array}$ & 17 & 4 & 3.94 & 0.966 \\
\hline $\begin{array}{l}\text { STDs must be able to meet the needs of tourists alike, as well as that of } \\
\text { their residents. }\end{array}$ & 17 & 5 & 4.71 & 0.470 \\
\hline $\begin{array}{l}\text { Promoting the creation of an STD requires that the public initiative lead the } \\
\text { process and be done in a planned way }\end{array}$ & 17 & 4 & 3.94 & 1.088 \\
\hline $\begin{array}{l}\text { The proposals directed from the bottom up, from residents and the local } \\
\text { community, are preferable to those directed from the top down from those } \\
\text { responsible for administration and institutions, to implement smart } \\
\text { tourism strategies. }\end{array}$ & 17 & 5 & 3.94 & 1.144 \\
\hline $\begin{array}{l}\text { STD planning and management requires a recurring public } \\
\text { participation process. }\end{array}$ & 17 & 5 & 4.53 & 0.717 \\
\hline
\end{tabular}

Source: Own elaboration.

Regarding frequencies, $88.2 \%$ of the respondents agreed or totally agreed that STDs have specific features that characterize and differentiate them from other tourist destinations. With respect to the item that STDs respond more to a fashion concept or a poorly defined denomination that at a verifiable reality, $58.8 \%$ disagreed. 
For $41.2 \%$ of the experts, there is no clear and widely accepted definition of what an STD is, but $64.7 \%$ agreed that technology and innovation in tourism should be a main strategic component of an STD.

For $76.5 \%$ of the participants, sustainability and equity should be the main strategic component of an STD, and the same percentage agreed that efficiency in the provision of tourist services should be a main strategic component of an STD. All of the respondents agreed that STDs must be able to equally meet the needs of tourists and local residents.

The vast majority $(76.5 \%)$ agreed or strongly agreed that promoting the creation of STD requires that public initiatives should lead the process and be done in a planned manner. While $70.6 \%$ agreed that proposals addressed from the bottom up, from residents and the local community, are preferable to those directed from the top down, from those responsible for administration and institutions, to implement smart tourism strategies; for $88.2 \%$ of the experts, planning and management of STD requires a recurring public participation process.

For the practical case, the variables Technology and innovation in tourism should be the main strategic component of an STD is the variable best explained by the four factors because it registered the highest communalities (Table 2). The value of 0.911 means that $91.1 \%$ of the variability of Technology and innovation in tourism should be the main strategic component of an STD is explained by the four factors, while the value of 0.565 means that the variable The STDs respond more to a concept of fashion or a poorly defined denomination that to a verifiable reality is explained in only $56.5 \%$ of the four factors.

Table 2. Commonality of expert assessment on the concept of STD and its strategic orientation.

\begin{tabular}{|c|c|c|}
\hline & Initial & Extraction \\
\hline $\begin{array}{l}\text { STDs have specific features that characterize them and allow them to differentiate from other } \\
\text { tourist destinations. }\end{array}$ & 1.000 & 0.668 \\
\hline STDs respond more to a fashion concept or a poorly defined denomination than to a verifiable reality. & 1.000 & 0.565 \\
\hline There is a clear and widely accepted definition of what an STD is. & 1.000 & 0.738 \\
\hline Technology and innovation in tourism should be the main strategic component of an STD. & 1.000 & 0.911 \\
\hline Sustainability and equity should be the main strategic component of an STD & 1.000 & 0.835 \\
\hline Efficiency in the provision of tourism services should be the main strategic component of an STD. & 1.000 & 0.826 \\
\hline STDs must be able to meet the needs of tourists alike, as well as that of their residents. & 1.000 & 0.830 \\
\hline $\begin{array}{l}\text { Promoting the creation of an STD requires that the public initiative lead the process and be done in a } \\
\text { planned way. }\end{array}$ & 1.000 & 0.687 \\
\hline $\begin{array}{l}\text { The proposals directed from bottom up, from residents and the local community, are preferable to } \\
\text { those directed from top down from those responsible for administration and institutions, to } \\
\text { implement smart tourism strategies. }\end{array}$ & 1.000 & 0.788 \\
\hline STD planning and management requires a recurring public participation process. & 1.000 & 0.658 \\
\hline
\end{tabular}

Table 3 shows the variance of the model that is explained by the four factors or components. The column "Extraction Sums of Squared Loadings" indicates that the first component explains 30.9\% of the total variation, the second component $18.0 \%$, the third $13.3 \%$, and the fourth $12.8 \%$. Thus, among the four factors, they explain $75.0 \%$ of the behavior of the experts' assessment of the concept of STD and its strategic orientation.

The second aspect analyzed addresses the perceptions that the experts hold about the competitive capacity of STDs as innovative business models.

Table 4 shows that the participants hold a positive assessment of the competitive capacity of the STDs as innovative business models, as all the variables have values greater than 3 , with an overall average of 4.02; this value is higher to that found by González et al. (3.68) [2].

Regarding the frequencies, $70.6 \%$ of the respondents agreed or totally agreed that STDs have competitive advantages based on the uniqueness and differentiation of the product in relation to other tourist destinations. In relation to the STD presenting competitive advantages based on the improvement of the image in relation to other tourist destinations, $94.1 \%$ agreed and strongly agreed. 
Table 3. Explained variance of the experts' assessment of the concept of STD and its strategic orientation.

\begin{tabular}{|c|c|c|c|c|c|c|}
\hline \multirow{2}{*}{ Component } & \multicolumn{3}{|c|}{ Initial Eigenvalues } & \multicolumn{3}{|c|}{ Extraction Sums of Squared Loadings } \\
\hline & Total & $\%$ of Variance & Cumulative \% & Total & $\%$ of Variance & Cumulative $\%$ \\
\hline 1 & 3.090 & 30.900 & 30.900 & 3.090 & 30.900 & 30.900 \\
\hline 2 & 1.804 & 18.038 & 48.938 & 1.804 & 18.038 & 48.938 \\
\hline 3 & 1.331 & 13.309 & 62.247 & 1.331 & 13.309 & 62.247 \\
\hline 4 & 1.282 & 12.817 & 75.064 & 1.282 & 12.817 & 75.064 \\
\hline 5 & 0.885 & 8.855 & 83.919 & & & \\
\hline 6 & 0.683 & 6.832 & 90.751 & & & \\
\hline 7 & 0.418 & 4.176 & 94.927 & & & \\
\hline 8 & 0.288 & 2.884 & 97.811 & & & \\
\hline 9 & 0.146 & 1.456 & 99.267 & & & \\
\hline 10 & 0.073 & 0.733 & 100.000 & & & \\
\hline
\end{tabular}

Table 4. Descriptive statistics of the experts' assessment of the competitive capacity of STDs.

\begin{tabular}{|c|c|c|c|c|}
\hline & $\mathbf{N}$ & Mode & Mean & Std. Deviation \\
\hline \multicolumn{5}{|l|}{ Innovative business models } \\
\hline \multicolumn{5}{|l|}{ Overall assessment of the competitiveness of STDs } \\
\hline $\begin{array}{l}\text { STDs have competitive advantages based on the uniqueness and product } \\
\text { differentiation in relation to other tourist destinations. }\end{array}$ & 17 & 4 & 3.94 & 0.899 \\
\hline $\begin{array}{l}\text { The STDs have competitive advantages based on the improvement of the } \\
\text { image in relation to other tourist destinations. }\end{array}$ & 17 & 4 & 4.12 & 0.485 \\
\hline $\begin{array}{l}\text { In the future, destinations that do not include smart tourism will be out of } \\
\text { play in the framework of global competitiveness. }\end{array}$ & 17 & 4 & 3.71 & 1.105 \\
\hline $\begin{array}{l}\text { In the future, most STDs will end up incorporating products and business } \\
\text { forms that are standardized and little differentiated from each other. }\end{array}$ & 17 & 4 & 4.00 & 0.866 \\
\hline $\begin{array}{l}\text { The STD will allow the creation of new tourism companies with } \\
\text { technological content. }\end{array}$ & 17 & 4 & 4.24 & 0.437 \\
\hline STDs will be associated with the emergence of innovative business models. & 17 & 4 & 4.18 & 0.529 \\
\hline $\begin{array}{l}\text { New technology-focused business models will tend to replace rather than } \\
\text { complement existing ones. }\end{array}$ & 17 & 5 & 3.76 & 1.251 \\
\hline $\begin{array}{l}\text { The business models that will generate STDs will have greater productivity } \\
\text { compared to the current ones. }\end{array}$ & 17 & 4 & 4.00 & 0.612 \\
\hline STDs will promote business models based on the collaborative economy. & 17 & 5 & 4.06 & 1.029 \\
\hline \multicolumn{5}{|l|}{ Tourist Experience } \\
\hline $\begin{array}{l}\text { The tourist experiences that will take place in the STD will be substantially } \\
\text { different from the current. }\end{array}$ & 17 & 4 & 4.06 & 0.966 \\
\hline $\begin{array}{l}\text { The co-creation of experiences (between the users themselves and other } \\
\text { actors of the destination) will be essential to generate experiences in STDs. }\end{array}$ & 17 & 5 & 4.06 & 1.029 \\
\hline $\begin{array}{l}\text { The personalization of experiences and the proposal of customized } \\
\text { experiences will be generalized to STDs. }\end{array}$ & 17 & 4 & 4.00 & 0.935 \\
\hline $\begin{array}{l}\text { Practices based on smart tourism will improve experiences in the pre and } \\
\text { post visit phases. }\end{array}$ & 17 & 4 & 4.41 & 0.618 \\
\hline \multicolumn{5}{|l|}{ New markets and satisfaction } \\
\hline $\begin{array}{l}\text { Currently, the demand for tourist experiences in STDs is a minority of } \\
\text { tourists. }\end{array}$ & 17 & 4 & 3.59 & 1.176 \\
\hline $\begin{array}{l}\text { Demand segments that will seek experiences and products based on smart } \\
\text { tourism will grow in the future. }\end{array}$ & 17 & 4 & 4.35 & 0.606 \\
\hline $\begin{array}{l}\text { The introduction of smart tourism will increase the level of global } \\
\text { satisfaction among the visitors of the destination. }\end{array}$ & 17 & 4 & 3.88 & 0.781 \\
\hline
\end{tabular}

Source: Own elaboration.

For $70.6 \%$ of the experts, in the future destinations that do not include smart tourism will be less competitive in the global tourism competitiveness; for $76.1 \%$ of the experts, in the future, most STDs will be incorporating standardized and poorly differentiated products and business forms each. 
For $100 \%$ of experts, STDs will allow the creation of new tourism companies with technological content, while for $94.1 \%$, the STDs will be associated with the emergence of innovative business models, and $58.8 \%$ of experts agree that new technology-focused business models will tend to replace, rather than complement, existing ones.

The vast majority $(82.3 \%)$ agree or strongly agree that business models generated for STDs will have higher productivity compared to the current ones, while $76.5 \%$, believe that STDs will promote models of business based on the collaborative economy. For $82.4 \%$, tourist experiences that will take place in STDs will be substantially different from current ones.

For $76.5 \%$ of experts, the co-creation of experiences (between the users themselves and other actors of the destination) will be essential to generate experiences in the STD; for $70.6 \%$, the personalization of the experiences and the proposal of customized experiences will be generalize to STDs. For $94.2 \%$, practices based on smart tourism will improve experiences in the pre and post visit phases.

Almost $60 \%$ (58.8\%) of experts agree that current demand for enjoying tourist experiences in STDs is a minority of tourists, but $94.1 \%$ of the respondents agree that demand for STD experiences and products will grow in the future. Three-quarters of the experts $(76.4 \%)$ agree that the introduction of smart tourism will increase the levels of satisfaction among visitors to the destination.

For the case study, the item STDs have competitive advantages based on the singularization and product differentiation in relation to other tourist destinations is the variable best explained by the five factors (Table 5). The value of 0.946 means that $94.6 \%$ of the variability of the item is explained by the five factors. The variable The tourist experiences that will take place in the STDs will be substantially different from the current ones possesses the lowest value, with only $72.2 \%$ explained by the five factors.

Table 5. Commonality of the assessment of experts on the competitive capacity of STDs.

\begin{tabular}{|c|c|c|}
\hline & Initial & Extraction \\
\hline $\begin{array}{l}\text { STDs have competitive advantages based on the uniqueness and product differentiation in } \\
\text { relation to other tourist destinations. }\end{array}$ & 1.000 & 0.946 \\
\hline $\begin{array}{l}\text { The STDs have competitive advantages based on the improvement of the image in relation to } \\
\text { other tourist destinations. }\end{array}$ & 1.000 & 0.875 \\
\hline $\begin{array}{l}\text { In the future, destinations that do not include smart tourism will be out of play in the } \\
\text { framework of global competitiveness. }\end{array}$ & 1.000 & 0.796 \\
\hline $\begin{array}{l}\text { In the future, most STDs will end up incorporating products and business forms that are } \\
\text { standardized and little differentiated from each other. }\end{array}$ & 1.000 & 0.762 \\
\hline The STD will allow the creation of new tourism companies with technological content. & 1.000 & 0.765 \\
\hline STDs will be associated with the emergence of innovative business models. & 1.000 & 0.779 \\
\hline $\begin{array}{l}\text { New technology-focused business models will tend to replace rather than complement } \\
\text { existing ones. }\end{array}$ & 1.000 & 0.884 \\
\hline $\begin{array}{l}\text { The business models that will generate STDs will have greater productivity compared to the } \\
\text { current ones. }\end{array}$ & 1.000 & 0.796 \\
\hline STDs will promote business models based on the collaborative economy. & 1.000 & 0.875 \\
\hline $\begin{array}{l}\text { The tourist experiences that will take place in the STD will be substantially different from } \\
\text { the current. }\end{array}$ & 1.000 & 0.722 \\
\hline $\begin{array}{l}\text { The co-creation of experiences (between the users themselves and other actors of the } \\
\text { destination) will be essential to generate experiences in STDs. }\end{array}$ & 1.000 & 0.758 \\
\hline $\begin{array}{l}\text { The personalization of experiences and the proposal of customized experiences will be } \\
\text { generalized to STDs. }\end{array}$ & 1.000 & 0.921 \\
\hline Practices based on smart tourism will improve experiences in the pre and post visit phases. & 1.000 & 0.879 \\
\hline $\begin{array}{l}\text { Currently, the demand that may be interested in enjoying tourist experiences in STDs is } \\
\text { a minority. }\end{array}$ & 1.000 & 0.814 \\
\hline $\begin{array}{l}\text { Demand segments that will seek experiences and products based on smart tourism will grow } \\
\text { in the future. }\end{array}$ & 1.000 & 0.882 \\
\hline $\begin{array}{l}\text { The introduction of smart tourism will increase the level of global satisfaction among the } \\
\text { visitors of the destination. }\end{array}$ & 1.000 & 0.909 \\
\hline \multicolumn{3}{|l|}{ Extraction Method: Principal Component Analysis. } \\
\hline
\end{tabular}


Table 6 shows the percentage of variance of the model that is explained by the five factors. The column "Extraction Sums of Squared Loadings" indicates that the first component explains $44.1 \%$ of the total variation, and the second component explains $13.7 \%$, while the third component is $10.1 \%$, the fourth component is $8.5 \%$, and the fifth is $7.2 \%$. Thus, among the five factors, they explain $83.5 \%$ of the behavior of the experts' assessment of competitive capacity of the STDs as an innovative business model.

Table 6. Explained variance of the experts' assessment of the competitive capacity of STDs.

\begin{tabular}{|c|c|c|c|c|c|c|}
\hline \multirow{2}{*}{ Component } & \multicolumn{3}{|c|}{ Initial Eigenvalues } & \multicolumn{3}{|c|}{ Extraction Sums of Squared Loadings } \\
\hline & Total & \% of Variance & Cumulative \% & Total & $\%$ of Variance & Cumulative $\%$ \\
\hline 1 & 7.064 & 44.149 & 44.149 & 7.064 & 44.149 & 44.149 \\
\hline 2 & 2.187 & 13.668 & 57.817 & 2.187 & 13.668 & 57.817 \\
\hline 3 & 1.611 & 10.070 & 67.887 & 1.611 & 10.070 & 67.887 \\
\hline 4 & 1.352 & 8.451 & 76.338 & 1.352 & 8.451 & 76.338 \\
\hline 5 & 1.150 & 7.185 & 83.523 & 1.150 & 7.185 & 83.523 \\
\hline 6 & 0.662 & 4.137 & 87.660 & & & \\
\hline 7 & 0.523 & 3.271 & 90.931 & & & \\
\hline 8 & 0.486 & 3.035 & 93.966 & & & \\
\hline 9 & 0.391 & 2.441 & 96.408 & & & \\
\hline 10 & 0.228 & 1.427 & 97.835 & & & \\
\hline 11 & 0.138 & 0.862 & 98.697 & & & \\
\hline 12 & 0.090 & 0.562 & 99.259 & & & \\
\hline 13 & 0.064 & 0.401 & 99.660 & & & \\
\hline 14 & 0.040 & 0.252 & 99.912 & & & \\
\hline 15 & 0.014 & 0.087 & 100.000 & & & \\
\hline 16 & $6.268 \times 10^{-5}$ & 0.000 & 100.000 & & & \\
\hline
\end{tabular}

Source: Own elaboration.

The third aspect analyzed refers to the experts' perceptions regarding factors the implementation of an STD project in Puerto Vallarta, such as the conditions of destination departure, endogenous factors, ability to innovate, and the ability to promote governance policies.

Table 7 shows that the respondents have a positive assessment of the factors that determine the implementation of the STD project, such as endogenous factors, ability to innovate, and the ability to promote policies of governance; all variables have values greater than three, except the variable Tourist destinations in general have sufficient starting conditions (management knowledge, human and technical capital and financial capacity) to be able to become an STD, which is 2.76 The overall average is 4.09 , a greater value to that found by González et al. (3.87) in his study conducted in Spain [2].

Table 7. Descriptive statistics of the experts' assessment of the factors that condition the implementation of STD projects.

\begin{tabular}{|c|c|c|c|c|}
\hline & $\mathbf{N}$ & Mode & Mean & Std. Deviation \\
\hline \multicolumn{5}{|l|}{$\begin{array}{l}\text { Conditioning factors } \\
\text { Destination starting conditions }\end{array}$} \\
\hline $\begin{array}{c}\text { Tourist destinations in general have sufficient starting conditions } \\
\text { (management knowledge, human and technical capital, and financial } \\
\text { capacity) to become STDs. }\end{array}$ & 17 & 2 & 2.76 & 1.147 \\
\hline $\begin{array}{l}\text { Business models require specialized workers who currently do not have } \\
\text { the destinations. }\end{array}$ & 17 & 4 & 3.71 & 1.047 \\
\hline $\begin{array}{c}\text { In general, destination managers lack technological knowledge and are } \\
\text { unaware of the usefulness of the main technologies that support } \\
\text { smart tourism. }\end{array}$ & 17 & 4 & 4.12 & 0.600 \\
\hline $\begin{array}{l}\text { It is not possible to introduce smart tourism measures without having big } \\
\text { data, cloud computing, and Internet of Things infrastructure } \\
\text { and equipment. }\end{array}$ & 17 & 4 & 4.12 & 0.928 \\
\hline
\end{tabular}


Table 7. Cont.

\begin{tabular}{|c|c|c|c|c|}
\hline & $\mathbf{N}$ & Mode & Mean & Std. Deviation \\
\hline \multicolumn{5}{|l|}{ Endogenous factors } \\
\hline Life cycle in which the destination is located & 17 & 4 & 3.76 & 0.970 \\
\hline $\begin{array}{l}\text { Predominant tourist modality in the destination (urban, sun and beach, } \\
\text { rural, etc.). }\end{array}$ & 17 & 4 & 4.00 & 1.061 \\
\hline $\begin{array}{l}\text { Budget capacity of the public sector to make investments in technology } \\
\text { applied to tourism. }\end{array}$ & 17 & 4 & 4.00 & 1.061 \\
\hline $\begin{array}{l}\text { Ability to capture private investments to develop technology projects } \\
\text { applied to tourism. }\end{array}$ & 17 & 4 & 4.35 & 0.493 \\
\hline Tourism demand with technological skills (millennials, youth, etc.). & 17 & 4 & 4.18 & 0.951 \\
\hline Ability to influence markets through tourism promotion. & 17 & 5 & 4.24 & 0.903 \\
\hline \multicolumn{5}{|l|}{ Factors related to the ability to innovate } \\
\hline $\begin{array}{l}\text { Ability to digitally integrate the tourism system and collect and process } \\
\text { information through the internet. }\end{array}$ & 17 & 4 & 4.29 & 0.772 \\
\hline $\begin{array}{l}\text { Market perception or tourist image of the destination linked to } \\
\text { technological innovation. }\end{array}$ & 17 & 4 & 4.12 & 0.993 \\
\hline Ability to generate tourism products supported by technology. & 17 & 4 & 4.06 & 0.556 \\
\hline Ability to innovate in technology. & 17 & 4 & 4.24 & 0.664 \\
\hline Ability to boost the co-creation of tourist experiences. & 17 & 4 & 4.06 & 0.966 \\
\hline Entrepreneurship capacity. & 17 & 4 & 4.41 & 0.507 \\
\hline Ability to establish new business models based on new technologies. & 17 & 4 & 4.29 & 0.588 \\
\hline \multicolumn{5}{|l|}{ Factors related to the ability to promote governance policies } \\
\hline Leadership capacity of the administration and public institutions. & 17 & 4 & 4.35 & 0.606 \\
\hline $\begin{array}{l}\text { Ability to generate information in open and share it among the agents of } \\
\text { the destination. }\end{array}$ & 17 & 4 & 4.06 & 0.827 \\
\hline Ability to associate and collaborate among social agents. & 17 & 4 & 4.35 & 0.493 \\
\hline $\begin{array}{l}\text { Ability to promote strategies that link the networks of local and resident } \\
\text { social actors. }\end{array}$ & 17 & 4 & 4.24 & 0.562 \\
\hline Have a comprehensive physical accessibility system for destination visitors. & 17 & 4 & 4.24 & 0.831 \\
\hline Ability to integrate residents' point of view into tourism projects. & 17 & 4 & 4.12 & 0.993 \\
\hline
\end{tabular}

Source: Own elaboration.

With regard to frequencies, only $35.3 \%$ of the participants agree or totally agree that tourist destinations in general have sufficient starting conditions (management knowledge, human and technical capital, and financial capacity) to be able to convert to an STD. For business models that require specialized workers who currently do not have the destinations, $64.7 \%$ disagree and strongly agree.

For $88.2 \%$, in general, destination managers lack technological knowledge and are unaware of the usefulness of the main technologies that support smart tourism. For the same percentage, it is not possible to introduce smart tourism measures without having big data infrastructure and equipment, cloud computing, and Internet of Things.

For $64.7 \%$, the life cycle in which the destination is located is of paramount importance to become an STD, and for $82.4 \%$ the predominant tourist modality in the destination (urban, sun and beach, rural, etc.) would be relevant in the development of an STD. For $88.2 \%$ of experts, the budgetary capacity of the public sector to make investments in technology applied to tourism would be essential for an STD. One-hundred percent of the participants agree that the STD must have the capacity to attract private investments to develop technology projects applied to tourism.

The majority $(88.3 \%)$ of respondents agree or strongly agree on the existence of tourism demand with technological skills (millennials, young people, etc.); a similar percentage $(82.4 \%)$ of experts agree that STDs must have the capacity to influence markets through tourism promotion For $94.1 \%$, STDs 
must have the capacity to digitally integrate the tourism system and collect and process information through the internet.

For $82.4 \%$ of the experts, the STDs must generate the perception of a tourism market or tourist image of the destination linked to technological innovation; for $88.2 \%$ the STDs must have the capacity to generate tourist products supported by technology. In this sense, the same percentage of experts believe that, STDs must be able to innovate in technology, and have the capacity to promote the co-creation of tourist experiences; $100 \%$ of the participants agreed that STDs must have entrepreneurial capacity. For $94.1 \%$, STDs must have the capacity to establish new business models based on new technologies, leadership capacity of the administration and public institutions.

While for $82.3 \%$ of the experts, the STDs must have the capacity to generate open information and share it among the destination tourism agents, for $100 \%$, the capacity for association and collaboration among the tourism agents; for $94.1 \%$, the capacity to promote strategies that link the networks of local and resident social actors; for $88.3 \%$, a comprehensive physical accessibility system for visitors; and for $82.4 \%$, the ability to integrate residents' point-of-view into tourism projects.

For the practical case, the variables Budget capacity of the public sector to make investments in technology applied to tourism and Ability to generate information a transparent manner and share it among the destination agents, are the variables best explained by the six factors (Table 8). The value of 0.944 means that $94.4 \%$ of the variability of the two variables is explained by the six factors. At the other end of the scale, Capacity to capture private investments to develop projects of technology applied to tourism is explained by only $49.1 \%$ by the six factors.

Table 8. Commonality of the assessment of experts on the factors that condition the implementation of STD projects.

\begin{tabular}{|c|c|c|}
\hline & Initial & Extraction \\
\hline $\begin{array}{l}\text { Tourist destinations in general have sufficient starting conditions (management knowledge, human and } \\
\text { technical capital and financial capacity) to become STDs. }\end{array}$ & 1.000 & 0.654 \\
\hline Business models require entrepreneurs and specialized workers who currently have no destinations. & 1.000 & 0.802 \\
\hline $\begin{array}{l}\text { In general, destination managers lack technological knowledge and are unaware of the usefulness of the } \\
\text { main technologies that support smart tourism. }\end{array}$ & 1.000 & 0.815 \\
\hline $\begin{array}{l}\text { It is not possible to introduce smart tourism measures without having big data, cloud computing, and } \\
\text { Internet of Things infrastructure and equipment. }\end{array}$ & 1.000 & 0.793 \\
\hline Life cycle in which the destination is located. & 1.000 & 0.792 \\
\hline Predominant tourist modality in the destination (urban, sun and beach, rural, etc.). & 1.000 & 0.843 \\
\hline Budget capacity of the public sector to make investments in technology applied to tourism. & 1.000 & 0.944 \\
\hline Ability to capture private investments to develop technology projects applied to tourism. & 1.000 & 0.491 \\
\hline Existence of tourism demand with technological skills (millennials, youth, etc.). & 1.000 & 0.898 \\
\hline Ability to influence markets through tourism promotion. & 1.000 & 0.898 \\
\hline Ability to digitally integrate the tourism system and collect and process information through the internet. & 1.000 & 0.832 \\
\hline Market perception or tourist image of the destination linked to technological innovation. & 1.000 & 0.925 \\
\hline Ability to generate tourism products supported by technology. & 1.000 & 0.788 \\
\hline Ability to innovate in technology. & 1.000 & 0.849 \\
\hline Ability to boost the co-creation of tourist experiences. & 1.000 & 0.886 \\
\hline Entrepreneurship capacity. & 1.000 & 0.882 \\
\hline Ability to establish new business models based on new technologies & 1.000 & 0.911 \\
\hline Leadership capacity of the administration and public institutions. & 1.000 & 0.917 \\
\hline Ability to generate information in open and share it among the agents of the destination. & 1.000 & 0.944 \\
\hline Ability to associate and collaborate among social agents. & 1.000 & 0.934 \\
\hline Ability to promote strategies that link the networks of local and resident social actors. & 1.000 & 0.768 \\
\hline Have a comprehensive physical accessibility system for destination visitors. & 1.000 & 0.895 \\
\hline Ability to integrate residents' point of view into tourism projects. & 1.000 & 0.901 \\
\hline Extraction Method: Principal Component Analysis. & & \\
\hline
\end{tabular}


Table 9 shows the percentage of variance of the model that is explained by the six factors or components. The column "Extraction Sums of Squared Loadings" indicates that the first component accounts for $43.7 \%$ of the total variation, the second component for $11.8 \%$, the third $9.4 \%$, the fourth $7.9 \%$, the fifth $6.2 \%$, and the sixth $5.2 \%$. Thus, the six factors explain $84.2 \%$ of the valuation behavior on the factors that condition the implementation of the STD project.

Table 9. Explained variance of the experts' assessment of the factors that condition the implementation of STD projects.

\begin{tabular}{|c|c|c|c|c|c|c|}
\hline \multirow{2}{*}{ Component } & \multicolumn{3}{|c|}{ Initial Eigenvalues } & \multicolumn{3}{|c|}{ Extraction Sums of Squared Loadings } \\
\hline & Total & $\%$ of Variance & Cumulative \% & Total & $\%$ of Variance & Cumulative $\%$ \\
\hline 1 & 10.057 & 43.728 & 43.728 & 10.057 & 43.728 & 43.728 \\
\hline 2 & 2.721 & 11.830 & 55.557 & 2.721 & 11.830 & 55.557 \\
\hline 3 & 2.153 & 9.363 & 64.920 & 2.153 & 9.363 & 64.920 \\
\hline 4 & 1.823 & 7.927 & 72.847 & 1.823 & 7.927 & 72.847 \\
\hline 5 & 1.420 & 6.174 & 79.022 & 1.420 & 6.174 & 79.022 \\
\hline 6 & 1.189 & 5.171 & 84.193 & 1.189 & 5.171 & 84.193 \\
\hline 7 & 0.787 & 3.421 & 87.614 & & & \\
\hline 8 & 0.704 & 3.060 & 90.674 & & & \\
\hline 9 & 0.637 & 2.771 & 93.445 & & & \\
\hline 10 & 0.462 & 2.007 & 95.452 & & & \\
\hline 11 & 0.339 & 1.472 & 96.924 & & & \\
\hline 12 & 0.299 & 1.302 & 98.226 & & & \\
\hline 13 & 0.246 & 1.071 & 99.297 & & & \\
\hline 14 & 0.126 & 0.547 & 99.844 & & & \\
\hline 15 & 0.025 & 0.108 & 99.951 & & & \\
\hline 16 & 0.011 & 0.049 & 100.000 & & & \\
\hline 17 & $5.887 \times 10^{-16}$ & $2.560 \times 10^{-15}$ & 100.000 & & & \\
\hline 18 & $4.225 \times 10^{-16}$ & $1.837 \times 10^{-15}$ & 100.000 & & & \\
\hline 19 & $-2.637 \times 10^{-17}$ & $-1.147 \times 10^{-16}$ & 100.000 & & & \\
\hline 20 & $-3.583 \times 10^{-16}$ & $-1.558 \times 10^{-15}$ & 100.000 & & & \\
\hline 21 & $-4.451 \times 10^{-16}$ & $-1.935 \times 10^{-15}$ & 100.000 & & & \\
\hline 22 & $-6.878 \times 10^{-16}$ & $-2.991 \times 10^{-15}$ & 100.000 & & & \\
\hline 23 & $-8.845 \times 10^{-16}$ & $-3.846 \times 10^{-15}$ & 100.000 & & & \\
\hline
\end{tabular}

Extraction Method: Principal Component Analysis.

\section{Source: Own elaboration.}

The fourth aspect analyzed addresses the of experts' assessment of the risks and limitations arising from the implementation of STD projects, such as the digital gap, security and privacy, acceptance of use in the tourist experience, and the intervention of private interests (Table 10).

Table 10. Descriptive statistics of the experts' assessment of the risks and limitations arising from the implementation of STD projects.

\begin{tabular}{|c|c|c|c|c|}
\hline & $\mathbf{N}$ & Mode & Mean & Std. Deviation \\
\hline \multicolumn{5}{|l|}{$\begin{array}{l}\text { Risks } \\
\text { Digital gap }\end{array}$} \\
\hline STDs can foster inequalities between tourist destinations derived from the digital gap. & 17 & 4 & 3.59 & 1.176 \\
\hline STDs can foster inequalities between tourism businesses arising from the digital gap. & 17 & 4 & 4.00 & 0.935 \\
\hline $\begin{array}{l}\text { STDs can foster inequalities between tourists and visitors based on their degree of } \\
\text { access, tolerance and understanding of technology. }\end{array}$ & 17 & 4 & 3.82 & 1.015 \\
\hline $\begin{array}{l}\text { The progressive dependence of mobile devices and technology to enjoy the tourist } \\
\text { experience will generate inequalities between users according to their degree of } \\
\text { technological experience. }\end{array}$ & 17 & 4 & 3.76 & 0.970 \\
\hline $\begin{array}{l}\text { Launching STD initiatives is within reach of few destinations given the infrastructure } \\
\text { and technology investment costs that it requires. }\end{array}$ & 17 & 5 & 3.82 & 1.286 \\
\hline \multicolumn{5}{|l|}{ Security and privacy } \\
\hline $\begin{array}{l}\text { Privacy in STDs will be affected by private use and for commercial interests in } \\
\text { personal data. }\end{array}$ & 17 & 4 & 4.18 & 0.728 \\
\hline $\begin{array}{l}\text { The security of users to STDs will be lower due to the increase in information traffic and } \\
\text { geo-referenced location of people. }\end{array}$ & 17 & 4 & 3.76 & 1.147 \\
\hline
\end{tabular}


Table 10. Cont.

\begin{tabular}{|c|c|c|c|c|}
\hline & $\mathbf{N}$ & Mode & Mean & Std. Deviation \\
\hline \multicolumn{5}{|l|}{ Acceptance of use in the tourist experience } \\
\hline $\begin{array}{l}\text { Acceptance of the use of technology and mobile devices among users can be low or very } \\
\text { low in certain segments of demand. }\end{array}$ & 17 & 4 & 4.00 & 0.935 \\
\hline $\begin{array}{l}\text { Smart tourism will generate interference and offers little room for maneuvering in the } \\
\text { decision-making of tourists. }\end{array}$ & 17 & 2 & 3.29 & 1.263 \\
\hline \multicolumn{5}{|l|}{ Intervention private interests } \\
\hline $\begin{array}{l}\text { The objectives of STDs focus more on technological improvements than on solving } \\
\text { everyday problems and sustainability at destination. }\end{array}$ & 17 & 4 & 3.76 & 1.033 \\
\hline $\begin{array}{l}\text { The cost of implementing smart tourism and associated technology will make large } \\
\text { groups and multinational companies (telephony, tech, etc.) gain influence on the } \\
\text { management and decision making of the destination. }\end{array}$ & 17 & 4 & 4.06 & 0.827 \\
\hline
\end{tabular}

Source: Own elaboration.

The table shows that the experts have a positive assessment of the risks and limitations arising from the implementation of STD projects. All the variables have values higher than 3 , with an overall average of the means of 3.82, higher value than the one found by González et al. (3.03) in his study conducted in Spain [2].

Regarding the frequencies, $64.7 \%$ of the respondents agreed or totally agreed that STDs can promote inequalities between tourist destinations derived from the digital gap; with respect to STDs can promote inequalities between tourism companies derived from the digital gap, $82.3 \%$ disagreed and strongly disagreed.

Three-quarters $(76.4 \%)$ of the experts believed that, in the future, STDs will promote inequalities between tourists and visitors according to their degree of access, tolerance and understanding of technology; for $76.4 \%$ of the respondents the progressive dependence of mobile devices and technology to enjoyment of the tourist experience will generate inequalities between users according to their degree of technological experience.

Slightly more than half (58.9\%) of the experts agreed that launching STD initiatives is available to few destinations, given the costs of infrastructure and technology investment required, and $82.4 \%$ agree that privacy in STDs will be affected by private use and for commercial interests in personal data; $64.7 \%$ of the participants agreed that the security of users in STDs will be lower due to the increase in information traffic and geo-referenced location of people.

The majority of experts $(82.3 \%)$ agreed or strongly agreed that the acceptance of the use of technology and mobile devices among users may be low or very low in certain segments of the tourist population, but less than half $(47.0 \%)$ believed that smart tourism will generate interference and offers little room for maneuver in the decision-making process of tourists; for $70.6 \%$ of the respondents, the objectives of STDs focus more on technological improvements than on solving daily problems and sustainability of the destination.

As for $82.3 \%$ of experts, the cost of implementing smart tourism and associated technology will make large groups and multinational companies (telephone, tech, etc.) gain influence on the management and decision-making of the destination.

For the case study, the variable STDs can promote inequalities between tourism companies derived from the digital gap is the variable best explained by the three factors (Table 11). The value of 0.837 means that $83.7 \%$ of the variability of the variable is explained by the three factors. The lowest value, 0.566 , means that the variable The security of the users to the STDs will be lower due to the increase in information traffic and the geo-referenced location of people is explained only $56.6 \%$ by the three factors. 
Table 11. Commonality of expert assessment on the risks and limitations arising from the implementation of STD projects.

\begin{tabular}{lcc}
\hline & Initial & Extraction \\
\hline STDs can foster inequalities between tourist destinations derived from the digital gap. & 1.000 & 0.711 \\
\hline STDs can foster inequalities between tourism businesses arising from the digital gap. & 1.000 & 0.837 \\
\hline $\begin{array}{l}\text { STDs can foster inequalities between tourists and visitors based on their degree of access, } \\
\text { tolerance, and understanding of technology. }\end{array}$ & 1.000 & 0.549 \\
\hline $\begin{array}{l}\text { The progressive dependence of mobile devices and technology to enjoy the tourist } \\
\text { experience will generate inequalities between users according to their degree of } \\
\text { technological experience. }\end{array}$ & 1.000 & 0.652 \\
\hline $\begin{array}{l}\text { Launching STD initiatives is within reach of few destinations given the infrastructure } \\
\text { and technology investment costs that it requires. }\end{array}$ & 1.000 & 0.729 \\
\hline $\begin{array}{l}\text { Privacy in STDs will be affected by private use and for commercial interests in } \\
\text { personal data. }\end{array}$ & 1.000 & 0.581 \\
\hline $\begin{array}{l}\text { The security of users to STDs will be lower due to the increase in information traffic and } \\
\text { geo-referenced location of people. }\end{array}$ & 1.000 & 0.566 \\
\hline $\begin{array}{l}\text { Acceptance of the use of technology and mobile devices among users can be low or very } \\
\text { low in certain segments of demand. }\end{array}$ & 1.000 & 0.703 \\
\hline $\begin{array}{l}\text { Smart tourism will generate interference and offers little room for maneuvering in the } \\
\text { decision-making of tourists. }\end{array}$ & 1.000 & 0.587 \\
\hline $\begin{array}{l}\text { The objectives of STDs focus more on technological improvements than on solving } \\
\text { everyday problems and sustainability at destination. }\end{array}$ & 1.000 & 0.829 \\
\hline $\begin{array}{l}\text { The cost of implementing smart tourism and associated technology will make large } \\
\text { groups and multinational companies (telephony, tech, etc.) gain influence on the } \\
\text { management and decision making of the destination. }\end{array}$ & 1.000 & 0.719 \\
\hline \multicolumn{1}{c}{ Extraction Method: Principal Component Analysis. } \\
\hline
\end{tabular}

Table 12 shows the percentage of variance of the model that is explained by the four factors or components. The column "Extraction Sums of Squared Loadings" indicates that the first component explains $37.2 \%$ of the total variation, the second explains $21.5 \%$, while the third is $9.2 \%$. Therefore, among the three factors, they explain $67.8 \%$ of the experts' assessment of the risks and limitations arising from the implementation of STD projects (Table 12).

Table 12. Explained variance of the experts' assessment of the risks and limitations arising from the implementation of STD projects.

\begin{tabular}{|c|c|c|c|c|c|c|}
\hline \multirow{2}{*}{ Component } & \multicolumn{3}{|c|}{ Initial Eigenvalues } & \multicolumn{3}{|c|}{ Extraction Sums of Squared Loadings } \\
\hline & Total & $\%$ of Variance & Cumulative \% & Total & $\%$ of Variance & Cumulative \% \\
\hline 1 & 4.088 & 37.168 & 37.168 & 4.088 & 37.168 & 37.168 \\
\hline 2 & 2.361 & 21.464 & 58.632 & 2.361 & 21.464 & 58.632 \\
\hline 3 & 1.011 & 9.191 & 67.824 & 1.011 & 9.191 & 67.824 \\
\hline 4 & 0.913 & 8.303 & 76.127 & & & \\
\hline 5 & 0.785 & 7.138 & 83.265 & & & \\
\hline 6 & 0.575 & 5.229 & 88.494 & & & \\
\hline 7 & 0.465 & 4.224 & 92.717 & & & \\
\hline 8 & 0.388 & 3.526 & 96.244 & & & \\
\hline 9 & 0.205 & 1.859 & 98.103 & & & \\
\hline 10 & 0.132 & 1.196 & 99.299 & & & \\
\hline 11 & 0.077 & 0.701 & 100.000 & & & \\
\hline \multicolumn{7}{|c|}{ Extraction Method: Principal Component Analysis. } \\
\hline
\end{tabular}

\section{Conclusions}

In comparing the results between Spain [2] and Mexico in this study, the Mexican experts surveyed have as a reference the successful Spanish experience since, although only one year exists between 
the studies; in all the areas considered, the Mexican experts showed slightly higher percentages of agreement to the variables than the Spanish experts.

Regarding the perception of the concept of STD, it is clear that leadership of private initiatives and the innovative implementation of technology is required, and that it is a worldwide trend strongly supported by the social equity and sustainability of the model.

The competitive capacity of Mexican tourism for the STD model is very good according to experts: new and differentiated tourism products are feasible; innovation and companies may be able to adopt a new paradigm in smart tourism; experts see that, through STDs, development with collaborative participation would be promoted, which implies greater equity and sustainability.

The participants in this study value the factors that determine the implementation of STDs as determinants; there are at least three of them: Training, Investment, and Governance. In the first one, a new STD model would totally displace the current tourism model; in the second, because by not generating and innovating, technology must be acquired at great costs; and in the third, there is uncertainty about the generation of new public policies that would accompany a new STD model to shield itself from corruption, as well as guarantee collaborative participation of the whole society.

According to Mexican experts, the risks and limitations of the STD model include the possibility of generating inequality between companies and users, strengthening of multinationals and possible dependence on STDs, and the issue of information security of users and companies.

Regarding factor analysis, the first aspect analyzed addressed the perceptions that experts have about what the mission and fundamental objectives of STDs must be. The factor analysis carried out has allowed us to determine that the most conditioning variables of the assessment situation of the experts on the concept of STD and its strategic orientation are: Technology and innovation in tourism should be the main strategic component of an STD, and sustainability and equity should be the main strategic component of an STD.

The second aspect analyzed addressed the perceptions that experts have about the competitive capacity of STDs as innovative business models. The factor analysis made it possible to determine that the most conditioning variables are STDs that have competitive advantages based on the singularization and differentiation of the product in relation to other tourist destinations, and the personalization of experiences and the proposal of customized experiences will be generalized to an STD.

The third aspect analyzed addressed the perceptions that experts have about the factors that condition the implementation of the STD project, such as the conditions of departure of the destination, endogenous factors, ability to innovate, and the ability to promote governance policies. The factor analysis carried out has allowed us to determine that the most conditioning variables are budget capacity of the public sector to make investments in technology applied to tourism and capacity to generate open information and share it among the agents of the destination.

The fourth aspect analyzed refers to the assessment of experts on the risks and limitations arising from the implementation of STD projects, such as the digital gap, security and privacy, acceptance of use in the tourist experience, and the intervention of private interests. The factor analysis made it possible to determine that the most conditioning variables of the situation are STDs can foster inequalities between tourism companies derived from the digital gap, and the objectives of STDs focus more on technological improvements than on the solution of daily and sustainability problems at destination.

The identification of four dimensions of 10 in the first aspect, five dimensions of 16 in the second, six dimensions of 23 in the third, and three dimensions of 11 in the fourth make it possible to analyze the results based on them, regardless of the original variables, for future analysis.

This research provides an initial approach to the perception of actors in the tourism sector in Puerto Vallarta about the possibility of designing an STD. It should be noted that this analysis presents some limitations. The most important is that it is based on perception of the participants in the study; it also should be noted that technological issues in establishing an STD in Puerto Vallarta is an important consideration, since ICT coverage is currently poor in the city; finally, the current study is focused on 
Puerto Vallarta and may not be transferrable to other destinations; however, this work is considered as a preliminary baseline and starting point for future research.

In this sense, Gretzel et al. [15] create initiatives around the world trying to build smart tourism ecosystems. However, the complexity of the sector makes it extremely difficult to go beyond specific innovations, such as platforms and services technology; however, the technological momentum in tourism advances is considerable and can be spearhead for continuous innovations in the sector, such as smart destinations and even smart beaches.

Author Contributions: J.L.C.O. had the initial idea of the manuscript and wrote an original draft, as well as provided the resources for the research and C.D.M. participated in the formal reviews. All authors have read and agreed to the published version of the manuscript.

Funding: This research received no external funding.

Acknowledgments: The authors thank the anonymous reviewers for their very helpful comments that contributed to the development of this paper.

Conflicts of Interest: The authors declare no conflict of interest.

\section{References}

1. Komninos, N.; Pallot, M.; Schaffers, H. Spetial issue on smart cities and the future Internet in Europe. J. Knowl. Econ. 2013, 4, 119-134. [CrossRef]

2. González Reverté, F.; Díaz Luque, P.; Gomis López, J.M.; Morales Pérez, S. Reflexiones sobre la percepción de los Destinos Turísticos Inteligentes españoles por parte de los actores turísticos. ARA J. Tour. Res. Revista de Investigación Turística 2018, 8, 21-35.

3. INVAT-TUR. Destinos turísticos inteligentes. In Manual Operativo Para la Configuración de Destinos Turísticos Inteligentes; INVAT-TUR: Valencia, Spain, 2015.

4. Lamsfus, C.; Alzua, U. Theoretical framework for a tourism Internet of Things: Smart Destinations. tourGUNE J. Tour. Hum. Mob. 2013, 2, 15-21.

5. Cobo Romaní, J.C. El concepto de tecnologías de la información. Benchmarking sobre las definiciones de las TIC en la sociedad del conocimiento. Zer Revista de Estudios de Comunicación 2009, 27, 295-318.

6. McKercher, B. Changing of the Guard in Tourism Resarch Leadership. Hong Kong Polytech. Univ. Hong Kong 2014, unpublished paper.

7. Buhalis, D. Tendencias y retos de turismo electrónico en la era de las redes sociales. Turismo y Nuevas Tecnologías-Seminario Técnico San José Costa Rica 2013, 14, 5-17.

8. Cerezo, A.; y Guevara, A. El papel estratégico de las tecnologías de la información y las comunicaciones en el turismo. Int. J. Inf. Syst. Softw. Eng. Big Co. (IJISEBC) 2015, 2, 52-69.

9. ménez Quintero, J.; Aldeanueva Fernández, I. Las tecnologías de la información y la comunicación en las PYMES turísticas andaluzas: Una perspectiva estratégica de clúster. Cuad. de Cien. Econ. y Emp. 2012, 62, $37-48$.

10. Buhalis, D.; Law, R. Progress in information technology and tourism management: 20 years on and 10 years after the Internet-The state of eTourism research. Tour. Manag. 2008, 29, 609-623. [CrossRef]

11. Miralbell, O.; Lamsfus, C.; Gomis, J.M.; González, F. Análisis de las ponencias del congreso TURITEC entre 1999 y 2010. In Proceedings of the Turitec 2012: IX Congreso Nacional Turismo y Tecnologías de la Información y las Comunicaciones, Málaga, Spain, 25-26 October 2012; pp. 498-517.

12. Parra López, E.; Santana Talavera, A. Tecnologías de la información y la comunicación en turismo. In 20 Años de la actividad turística en España; Síntesis: Madrid, Spain, 2014; pp. 279-292.

13. Baggio, R.; Cooper, C. Knowledge transfer in a tourism destination: The effects of a network structure. Ser. Ind. J. 2015, 4, 145-150. [CrossRef]

14. Li, Y.; Hu, C.; Huang, C.; Duan, L. The concept of smart tourism in the context of tourism information services. Tour. Manag. 2016, 58, 293-300. [CrossRef]

15. Gretzel, U.; Sigala, M.; Xiang, Z.; Koo, C. Smart tourism: Foundations and developments. Electron. Mark. 2015, 25, 179-188. [CrossRef]

16. Zhang, L.; Li, N.; Liu, M. On the basic concept of smarter tourism and its theoretical system. Tour. Trib. 2012, 27, 66-73. 
17. Dikaiakos, M.D.; Katsaros, D.; Mehra, P.; Pallis, G.; Vakali, A. Cloud computing: Distributed internet computing for IT and scientific research. IEEE Int. Comp. 2009, 13, 10-13. [CrossRef]

18. Wang, D.; Li, X.R.; Li, Y. China's smart tourism destination" initiative: A taste of the service-dominant logic. J. Dest. Mark. Manag. 2013, 2, 59-61. [CrossRef]

19. Huang, C.; Li, Y. In the 12th five-year plan, the system research of smarter tourism under the background of smarter cities. In Proceedings of the Annual Conference of Tourism Tribune, Beijing, China, 21-22 May 2011; pp. 55-68.

20. Marine-Roig, E.; Anton Clavé, S. A method for analysing large-scale UGC data for tourism: Application to the case of Catalonia. In Information and Communication Technologies in Tourism; Tussyadiah, I., Inversini, A., Eds.; Springer: Cham, Switzerland, 2015; pp. 3-17.

21. Xiang, Z.; Schwartz, Z.; Uysal, M. What types of hotels make their guests (un)happy? Text analytics of customer experiences in online reviews. In Information and Communication Technologies in Tourism; Tussyadiah, I., Inversini, A., Eds.; Springer: Cham, Switzerland, 2015; pp. 33-45.

22. Koltringer, C.; Dickinger, A. Analyzing destination branding and image from online sources: A web content mining approach. J. Bus. Res. 2015, 68, 1836-1843. [CrossRef]

23. Lu, W.; Stepchenkova, S. User-generated content as a research mode in tourism and hospitality applications: Topics, methods, and software. J. Hosp. Mark. Manag. 2015, 24, 119-154. [CrossRef]

24. Hidalgo, M.C.; Sicilia, M.; Ruiz, S. The effect of user-generated content on tourist behavior: The mediating role of destination image [Special issue]. Tour. Manag. Stud. 2014, 10, 158-164.

25. Jalilvand, M.R.; Samiei, N.; Dini, B.; Manzari, P.Y. Examining the structural relationships of electronic word of mouth, destination image, tourist attitude toward destination and travel intention: An integrated approach. J. Dest. Mark. Manag. 2012, 1, 134-143. [CrossRef]

26. Marine-Roig, E. A webometric analysis of travel blogs and reviews hosting: The case of Catalonia. J. Trav. Tour. Mark. 2014, 31, 381-396. [CrossRef]

27. González-Reverté, F. Building Sustainable Smart Destinations: An Approach Based on the Development of Spanish Smart Tourism Plans. Sustainability 2019, 11, 6874. [CrossRef]

28. Marine-Roig, E.; Anton Clavé, S. Tourism analytics with massive user-generated content: A case study of Barcelona. J. Dest. Mark. Manag. 2015, 4, 162-172. [CrossRef]

29. Buhalis, D.; Amaranggana, A. Smart Tourism Destinations. In Information and Communication Technologies in Tourism; En Xiang, Z., Tussyadiah, I., Eds.; Springer: Viena, Austria, 2013; pp. 553-564.

30. Zygaris, S. Smart city reference model: Assisting planners to conceptualize the building of smart city innovation ecosystems. J. Know. Econ. 2013, 4, 217-231. [CrossRef]

31. China Economic Net; Rong, A. Smart Travel Getting Popular in China. Available online: http://en.ce.cn/ Insight/201204/12/t20120412_23235803.shtml (accessed on 15 October 2019).

32. Celdrán-Bernabeu, M.A.; Mazón, J.; Ivars-Baidal, J.A.; Vera-Rebollo, J.F. Smart Tourism. Un estudio de mapeo sistemático, (Smart Tourism A systematic mapping study). Cuadernos de Turismo 2018, 41, 107-138.

33. Law, R.; Buhalis, D.; Cobanoglu, C. Progress on information and communication technologies in hospitality and tourism. Intern. J. Cont. Hosp. Manag. 2014, 26, 727-750. [CrossRef]

34. Koo, C.; Gretzel, U.; Hunter, W.C.; Chung, N. The role of IT in tourism. Asia Pacific J. Inf. Syst. 2015, 25, 99-104. [CrossRef]

35. Gretzel, U. Intelligent systems in tourism: A social science perspective. Ann. Tour. Res. 2011, 38, 757-779. [CrossRef]

36. Resnik, J. Destinos Inteligentes, el Nuevo Concepto en Viajes; Forbes Mexico. 2016. Available online: https://www.forbes.com.mx/forbes-life/destino-turistico-inteligente/ (accessed on 24 February 2020).

37. IIEG (Instituto de Información Estadística y Geográfica). Puerto Vallarta Diagnóstico Municipal Agosto 2019. Mexico. 2019. Available online: https://iieg.gob.mx/ns/wp-content/uploads/2019/11/Puerto-Vallarta.pdf (accessed on 24 February 2020).

38. SECTURJAL (Secretaría de Turismo de Jalisco). Estadísticas del sector turístico. Anuario Estadístico. Gobierno del Estado de Jalisco, México. 2017. Available online: https://secturjal.jalisco.gob.mx/invierte-enjalisco/estadisticas (accessed on 24 February 2020).

39. Green, H.; Hunter, C.; Moore, B. Application of the Delphi Technique in Tourism. Ann. Tour. Res. 1990, 17, 270-279. [CrossRef] 
40. Yeh, D.-Y.; Cheng, C.-H. Recommendation system for popular tourist attractions in Taiwanusing Delphi panel and repertory grid techniques. Tour. Manag. 2015, 46, 164-176. [CrossRef]

41. Landeta, J. El método Delphi. In Una Técnica de Previsiónpara la Incertidumbre; Ariel: Barcelona, Spain, 1999. 